\title{
Penguatan Konsumsi Rumah Tangga dan Edukasi Mini Buklet Kepada Civitas Akademika Unesa Terdampak Covid-19
}

\author{
Dhiah Fitrayati1 ${ }^{1}$ Muhammad Abdul Ghofur ${ }^{2}$, Albrian Fiky Prakoso ${ }^{3}$, Mohamad Arief Rafsanjani*4, \\ Eka Hendi Andriansyah 5
}

\author{
1,2,3,4,5Program Studi S1 Pendidikan Ekonomi, Fakultas Ekonomi, Universitas Negeri Surabaya \\ *e-mail: mohamadrafsanjani@unesa.ac.id
}

\begin{abstract}
The Covid-19 pandemic effect on the economic sector is quite heavy. Based on data from the Ministry of Manpower as of April 7, 2020, it was recorded that 39,977 companies in the formal sector chose to lay off their workers. A total of 1,010,579 workers were affected. This condition reduces the people's purchasing power. One of the efforts to avoid COVID-19 exposure is to live a healthy and nutritious lifestyle. In an effort to suppress the spread of Covid-19, the PKM Team provided Covid-19 prevention education through mini booklets and provided assistance in the form of commodities to increase body immunity for the Unesa academic community in the East Java region, especially Surabaya. The Unesa academic community who received Covid19 prevention education through mini booklets and provided assistance in the form of immune-boosting commodities as many as 20 people consisting of students and educational staff.
\end{abstract}

Keywords: Educating, mini booklets, covid19, community services

\begin{abstract}
Abstrak
Dampak pandemi Covid-19 terhadap sektor ekonomi cukup berat. Berdasarkan data Kementerian Ketenagakerjaan per 7 April 2020, tercatat sebanyak 39.977 perusahaan di sektor formal memilih merumahkan dan melakukan PHK terhadap pekerjanya. Total terdapat 1.010.579 orang pekerja yang terkena dampak. Kondisi tersebut berakibat pada menurunnya daya beli masyarakat. Padahal salah satu upaya pencegahan agar tidak mudah terinfeksi Covid-19 adalah dengan menjaga sistem imun tubuh melalui pola hidup sehat dan bergizi. Dalam upaya untuk menekan penyebaran Covid-19, Tim PKM memberikan edukasi pencegahan Covid-19 melalui mini buklet dan memberikan bantuan berupa komoditas peningkat daya imunitas tubuh bagi civitas akademika Unesa di wilayah Jawa Timur khususnya Surabaya. Civitas akademika Unesa yang mendapatkan edukasi pencegahan Covid-19 melalui mini buclet dan pemberian bantuan berupa komoditas peningkat daya imunitas tubuh sebanyak 20 orang yang terdiri dari mahasiswa dan tenaga kependidikan.
\end{abstract}

Kata kunci: Edukasi, mini buklet, covid19, pengabdian kepada masyarakat

\section{PENDAHULUAN}

Tahun 2020 dunia internasional dihadapkan pada kemunculan jenis virus baru yang berimbas pada kondisi perekonomian negara. Pada tanggal 11 Maret 2020 Organisasi Kesehatan Dunia (WHO) menetapkan Corona Virus Disease 2019 menjadi Pandemi Internasional. Hal tersebut mengindikasikan negara- negara di seluruh dunia harus segera merespon, mencegah serta menangani pandemi virus Corona, tak terkecuali Negara Indonesia.

Indonesia mengkonfirmasi kasus pertama infeksi virus corona penyebab Covid-19 pada awal Maret 2020. Data Badan Nasional Penanggulangan Bencana per 22 Mei 2020 menunjukkan Indonesia berada termasuk 33 negara dengan sebaran penderita Covid-19 terbanyak di dunia. Hampir seluruh wilayah menjadi zona merah. Sebanyak 20.796 orang terkonfirmasi positif Covid, 5.057 orang dinyatakan telah sembuh dan 1.326 orang meninggal dunia. Provinsi Jawa Timur menjadi wilayah terbesar kedua kasus COVID-19 dengan 3.129 kasus. (Badan Nasional Penanggulangan Bencana, 2020). Berikut data terbaru penyebaran COVID 19 per 22 Mei 2020. 


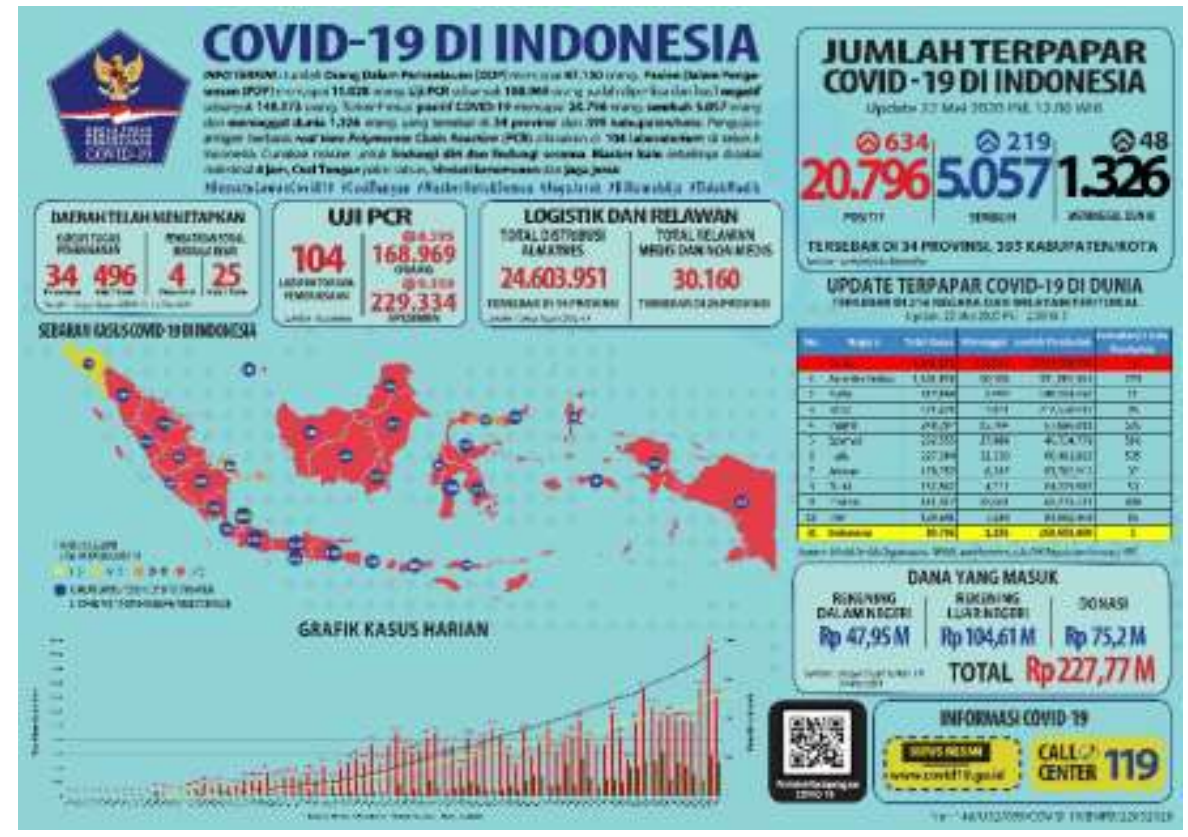

Gambar 1. Infografis Covid 19 Per 22 Mei 2020

(Sumber: Badan Nasional Penanggulangan Bencana, 2020)

Sejak itu, hampir seluruh sektor terdampak, termasuk sektor ekonomi. Dampak pandemi Covid-19 terhadap sektor ekonomi cukup berat. Laporan Badan Pusat Statistik (BPS) pada kuartal I menyebutkan bahwa pertumbuhan ekonomi Indonesia hanya 2,97\%, jauh lebih rebdah dari pertumbuhan ekonomi pada periode yang sama tahun 2019. Bahkan diprediksikan akan mencapai pertumbuhan ekonomi negatif pada kuartal II. Lemahnya kinerja ekonomi berdampak pada sektor ketenagakerjaan. Berdasarkan data Kementerian Ketenagakerjaan per 7 April 2020, tercatat sebanyak 39.977 perusahaan di sektor formal memilih merumahkan dan melakukan PHK terhadap pekerjanya. Total terdapat 1.010 .579 orang pekerja yang terkena dampak. Kondisi tersebut berakibat pada menurunnya daya beli masyarakat.

Data serupa dinyatakan oleh Wakil Direktur Institute for Development of Economics and Finance (Indef), Eko Listiyanto dalam video conference, Minggu (26/4/2020), menyatakan bahwa ekonomi Indonesia di tengah pandemi Covid-19 akan tumbuh sangat rendah. Jika pertumbuhan ekonomi di angka 2,5 persen maka peningkatan pengangguran bisa mencapai 3-4 juta (Ronal, 2020).

Propinsi Jawa Timur merupakan propinsi kedua dengan jumlah kasus covid terbesar di Indonesia. Dampak pandemi Covid-19 terhadap sektor ekonomi di Jawa Timur cukup berat. Pemerintah Propinsi Jawa Timur melalui Harian Kompas menyatakan bahwa hingga 11 Aprl 2020 terdapat 20.036 tenaga kerja dirumahkan dan 3.315 tenaga kerja terkena pemutusan hubungan kerja (PHK), selain itu terdapat 4.302 orang pekerja migran Indonesia (PMI) yang berdampak mulai dai pemutusan kontrak, bermasalah maupun gagal berangkat (Faizal, 2020).

Tingginya tingkat pengangguran di Jawa Timur memunculkan masalah baru yaitu menurunnya daya beli masyarakat. Badan Pusat Statistik menyebutkan selama bulan April Jawa Timur mengalami deflasi $0,12 \%$ dan berpengaruh terhadap daya beli masyarakat. Deflasi tersebut diperkirakan disebabkan oleh daya beli yang cenderung menurun selama masa pandemi. Dalam hal ini masyarakat cenderung membatasi konsumsi akibat menurunnya daya beli (Wijayanto, 2020).

Untuk mengantisipasi dampak yang ditimbulkan oleh pandemic covid19, Pemerintah Republik Indonesia Pada 31 Maret 2020, telah menerbitkan Peraturan Pemerintah Pengganti Undang-Undang (PERPPU) Nomor 1 Tahun 2020 tentang Kebijakan Keuangan Negara dan 
Stabilitas Sistem Keuangan Untuk Penanganan Pandemi Corona Virus Disease 2019 (Covid-19) dan/atau Dalam Rangka Menghadapi Ancaman Yang Membahayakan Perekonomian Nasional dan/atau Stabilitas Sistem Keuangan. PERPPU tersebut ditujukan untuk merelaksasi beberapa peraturan perundangan yang diperlukan dalam menghadapi Covid-19 dan menjaga stabilitas sistem keuangan (Puspasari, 2020). Selain itu, beberapa kegiatan mandiri yang di inisiasi oleh berbagai kalangan masyarakat untuk membantu penanganan dampak pandemic covid-19 telah terbukti sangat membantu masyarakat (Desmira, 2021; Hartati et al., 2021; Yarza et al., 2021; Rahmi et al., 2021).

Sejalan dengan kebijakan pemerintah, Universitas Negeri Surabaya sebagai salah satu unit dibawah kementerian negara ikut berperan dalam mendukung program pemerintah dalam upata menanggulangi Covid-19. Pembentukan Tim Unesa Crisis Center yang bertugas untuk penanggulangan dan memutus rantai Covid 19 pada civitas akademika di lingkungan kampus Unesa (Esti/Suryo, 2020).

Civitas akademika Universitas negeri Surabaya mayoritas bertempat tinggal di Jawa Timur baik Tenaga Pendidik, tenaga kependidikan maupun mahasiswanya. Pandemi Covid-19 juga berdampak pada berkurangnya pendapatan rumah tangga civitas akademika Unesa baik. Menurunnya pendapatan tersebut berdampak pada menurunnya daya beli rumah tangga. Padahal salah satu upaya pencegahan agar tidak mudah terinfeksi Covid-19 adalah dengan menjaga sistem imun tubuh melalui pola hidup sehat dan bergizi.

Dalam upaya untuk menekan penyebaran Covid-19, Tim PKM memberikan edukasi pencegahan Covid-19 melalui mini buklet dan memberikan bantuan berupa komoditas peningkat daya imunitas tubuh bagi civitas akademika Unesa di wilayah Jawa Timur khususnya Surabaya dan sekitarnya. Edukasi mini buklet berisi informasi tentang covid-19, bagaimana penyebarannya dan upaya antisipasi penyebarannya. Hasil dari pelaksanaan PKM ini diharapkan dapat menekan penyebaran Covid-19 dan meningkatnya daya imunitas masyarakat.

\section{METODE}

Pelaksanaan kegiatan pengabdian kepada masyarakat ini dilakukan dengan lima tahapan, yaitu:

\section{a. Observasi Awal}

Kegiatan observasi awal yang dilakukan mencakup dua hal, yaitu studi literatur tentang Covid-19 dan kegiatan pelacakan civitas akademika Unesa yang terdampak Covid-19. Kegiatan observasi awal pertama adalah studi literatur tentang Covid-19. Kegiatan ini dilakukan untuk memperoleh informasi tentang Covid-19 yang terdiri dari definisi, indikasi terinfeksi, pola dan media penyebaran serta langkah pencegahan. Informasi tersebut dibutuhkan sebagai data untuk menyusun mini buklet. Kegiatan observasi awal yang kedua adalah pelacakan civitas akademika yang terdampak Covid-19 dan identifikasi logistik yang dibutuhkan untuk meningkatkan daya imunitas tubuh.

\section{b. Penyusunan mini buklet yang bertema Covid-19: Penyebaran dan Pencegahan}

Mini buklet yang bertema Covid-19: Penyebaran dan Pencegahan beriksikan informasi tentang Covid-19 yang terdiri dari definisi, indikasi terinfeksi, pola dan media penyebaran serta langkah pencegahan. Mini buklet tersebut nantinya akan dibagikan ke pada civitas akademika Unesa yang terdampak Covid-19 sebagai bentuk edukasi tentang Covid-19. Hal ini dilakukan agar civitas akademika memahami bagaimana mencegah agar tidak terinfeksi Covid-19. Melalui edukasi ini diharapkan memberikan kontribusi terhadap penekanan penyebaran Covid-19 di Jawa Timur, khususnnya pada civitas akademika Unesa 
c. Pembelian logistik peningkatan daya imunitas tubuh

Logistik peningkatan daya imunitas tubuh meliputi vitamin, masker, hand sanitizer, dan kebutuhan pokok. Pemberian logistik peningkatan daya imunitas tubuh bertujuan untuk memperkuat konsumai rumah tangga khususnya pada komoditas yang dapat memperkuat imunitas tubuh.

\section{d. Pelaksanaan Kegiatan}

Lokasi pelaksanaan kegiatan di Fakultas Ekonomi Gedung G-5 Universitas Negeri Surabaya. Adapun jumlah civitas akademika terdampak yang diikutkan dalam kegiatan ini sebanyak 20 orang. Pelaksanaan kegiatan dilakukan secara luring dengan tetap memperhatikan protokol kesehatan. Oleh karenanya pembagian mini buklet dan logistik untuk meningkatkan daya imunitas tubuh dilakukan dalam 2 sesi dengan jumlah peserta 10 orang untuk masing-masng sesi.

e. Refleksi Kegiatan

Refleksi kegiatan dilakukan untuk mengidentifikasi ketepatan sasaran kegiatan dan kebermanfaatan kegiatan.

\section{HASIL DAN PEMBAHASAN}

Kegiatan pengabdian kepada masyarakat yang bertema "Penguatan Konsumsi Rumah Tangga dan Edukasi Mini Buklet Kepada Civitas Akademika Unesa Terdampak Covid-19" telah dilaksanakan pada hari Selasa, tanggal 6 oktober 2020 berlokasi di Gedung G-5 Fakultas Ekonomi Universitas Negeri Surabaya.

Kegiatan dilakukan dengan tetap memperhatikan protokol kesehatan. Penyaluran mini buklet dan bantuan logistik peningkatan daya imunitas tubuh dilakukan dalam 2 sesi. Sesi pertama dilaksanakan pukul 10.00-12.00 WIB, sedangkan sesi kedua dilaksanakan pukul 13.0015.00 WIB. Jumlah peserta untuk masing-masing sesi adalah 10 orang.

Peserta yang berpartisipasi dalam kegiatan ini adalah civitas akademika Unesa yang terdampak Covid-19 yang terdiri dari mahasiswa dan tenaga kependidikan Jurusan Pendidikan Ekonomi, Fakultas Ekonomi, Universitas Negeri Surabaya. Pemilihan peserta didasarkan pada data pelacakan mahasiswa yang orang tuanya terdampak Covid-19.

Adapun kegiatan terlaksana sesuai dengan rencana. Kegiatan dilaksanakan dengan runtut kegiatan sebagai berikut:

a. Kegiatan observasi awal telah dilaksanakan oleh tim PKM

Berbagai sumber informasi dan kiteratur ilmiah tentang Covid-19 telah diperoleh dan diverifikasi kebenarannya. Selain itu daftar mitra penerima edukasi dan bantuan logistik telah dilacak dan ditentukan. Begitu pula daftar logistik yang dibutuhkan untuk meningkatkan daya imunitas tubuh juga telah ditentukan.

b. Mini buklet yang bertema Covid-19: Penyebaran dan Pencegahan telah tersusun dan terdistribusikan.

Mini buklet yang bertema Covid-19: Penyebaran dan Pencegahan beriksikan informasi tentang Covid-19 yang terdiri dari definisi, indikasi terinfeksi, pola dan media penyebaran serta langkah pencegahan. Mini buklet tersebut dibagikan kepada civitas akademika Unesa yang terdampak Covid-19 sebagai bentuk edukasi tentang Covid-19. Melalui edukasi ini diharapkan memberikan kontribusi terhadap penekanan penyebaran Covid-19 di Jawa Timur, khususnnya pada civitas akademika Unesa. 

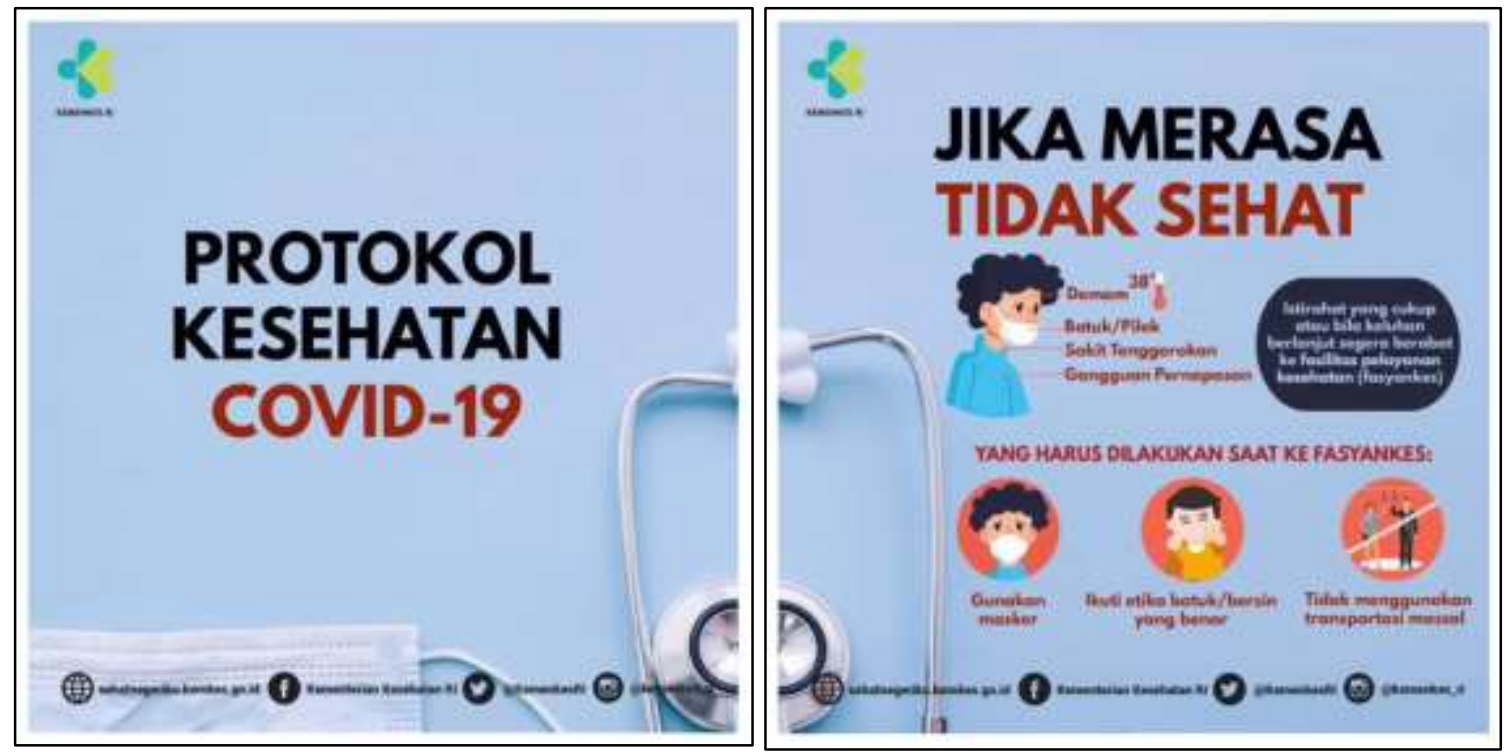

Gambar 2. Sampel mini buklet

c. Terdistribusinya logistik peningkatan daya imunitas tubuh

Pelaksanaan kegiatan dilakukan secara luring dengan tetap memperhatikan protokol kesehatan. Mengingat jumlah civitas akademika terdampak yang dilibatkan adalah 20 orang, maka pelaksanaan distribusi mini buklet dan bantuan logistik peningkatan daya imunitas tubuh dilakukan dalam 2 sesi dengan jumlah peserta 10 orang untuk masing-masng sesi pada hari yang sama

Logistik peningkatan daya imunitas tubuh meliputi vitamin, masker, hand sanitizer, dan kebutuhan pokok telah terdistibusi kepada civitas akademika terdampak Covid-19. Pemberian logistik peningkatan daya imunitas tubuh bertujuan untuk memperkuat konsumsi rumah tangga khususnya pada komoditas yang dapat memperkuat imunitas tubuh.
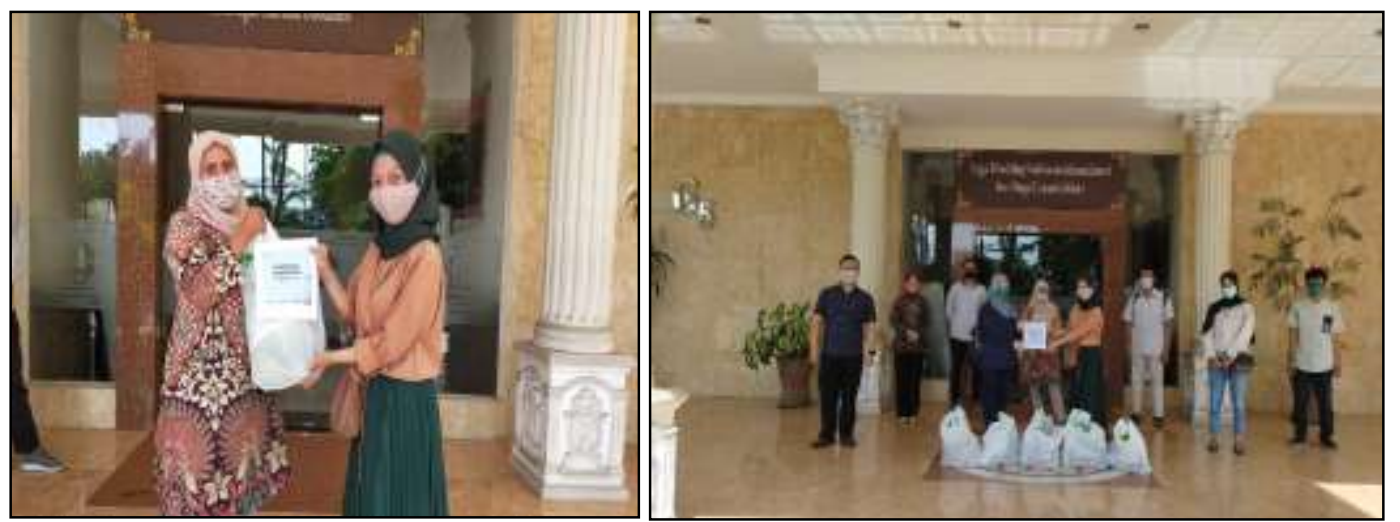

Gambar 3. Pelaksanaan distribusi mini buklet dan logistik PKM

\section{d. Refleksi kegiatan}

Dalam kegiatan ini, tim PKM memberikan kuesioner mengenai respon peserta untuk mendapatkan umpan balik. Ada dua aspek yang dinilai oleh peserta terhadap kegiatan ini, yaitu aspek mini buklet dan aspek bantuan logistik. 
Untuk aspek pertama yaitu mini buklet, peserta diminta untuk menilai kebermanfaatan dari materi yang terdapat dalam mini buklet yang telah disusun oleh tim PKM. Hasil pengolahan data menunjukkan bahwa $31 \%$ peserta (6 orang) memberikan respon bahwa mini buklet yang diberikan oleh tim PKM sangat bermanfaat dalam menambah pengetahuan terkait dengan covid19 dan langkah preventif yang harus dilakukan. Berikutnya sebanyak 64\% peserta (13 orang) menyatakan bahwa mini buklet tersebut bermanfaat, dan sisanya 6\% (1 orang) menyatakan cukup bermanfaat. Rekapitulasi respon peserta terhadap mini buklet dapat dilihat dalam gambar 4 berikut ini.

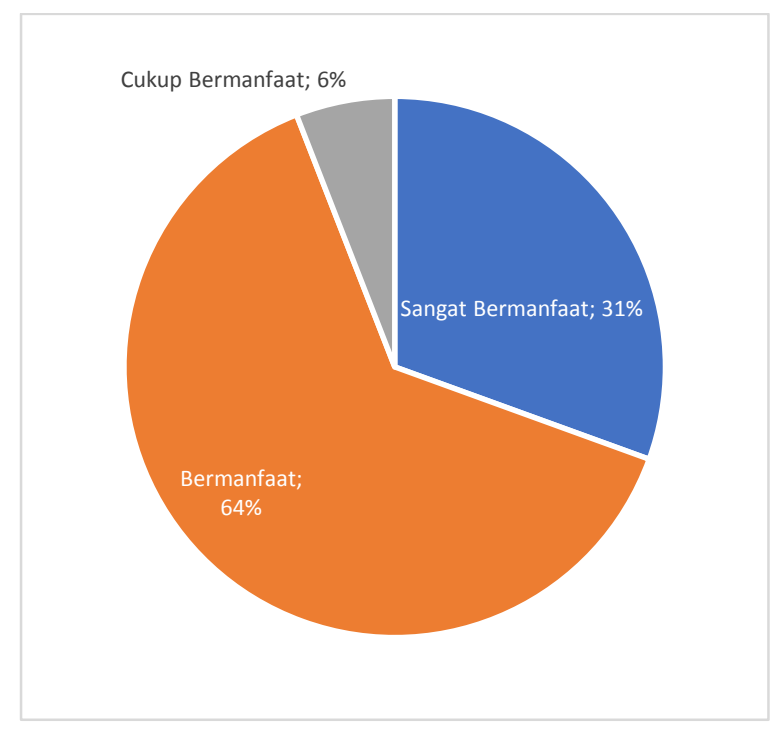

Gambar 4. Respon peserta terhadap mini buklet

Untuk aspek kedua yaitu bantuan logistik, peserta diminta untuk menilai kebermanfaatan dan kesesuaian dari bantuan logistik yang diberikan oleh tim PKM. Dari 20 civitas akademika yang menjadi sasaran dalam kegiatan ini, 13 orang (67\%) menyatakan bahwa bentuk bantuan logistik berupa vitamin, masker, hand sanitizer, dan kebutuhan pokok yang diberikan sangat sesuai dengan kebutuhan mereka saat ini ketika menghadapi pandemic covid19. Berikutnya sebanyak 6 orang (29\%) menyatakan sesuai dan sisanya 1 orang (5\%) menyatakan cukup sesuai. berikut ini.

Rekapitulasi respon peserta terhadap bantuan logistik dapat dilihat dalam gambar 5

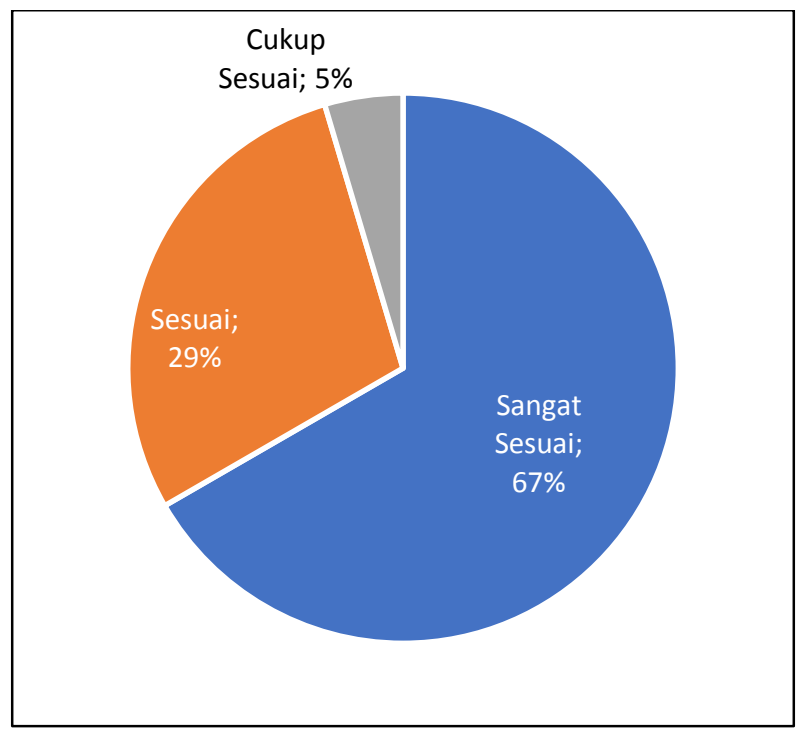

Gambar 5. Respon peserta terhadap bantuan logistik 


\section{KESIMPULAN}

Kegiatan pengabdian kepada masyarakat dengan tema Penguatan Konsumsi Rumah Tangga dan Edukasi Mini Buklet Kepada Civitas Akademika Unesa Terdampak Covid-19" telah memberikan bermanfaat bagi civitas akademika Unesa. Civitias akademika Unesa yang menjadi mitra kegiatan ini lebih memahami bagaimana pencegahan Covid-19. Dari sisi penguatan konsumsi rumah tangga, Civitas akademika Unesa yang menjadi mitra memperoleh bantuan logistik peningkatan daya imunitas tubuh meliputi vitamin, masker, hand sanitizer, dan kebutuhan pokok. Melalui pemberian bantuan tersebut diharapkan dapat meningkatkan daya beli.

\section{UCAPAN TERIMA KASIH}

Ucapan terimakasih untuk institusi Universitas Negeri Surabaya yang telah memberikan dukungan dana dalam kegiatan PKM tahun 2020.

\section{DAFTAR PUSTAKA}

Badan Nasional Penanggulangan Bencana. (2020). Infografis COVID-19 (22 Mei 2020). Retrieved from BNPB.com website: https://covid19.go.id/p/berita/infografis-covid-19-22-mei-2020

Desmira. (2021). Sosialisasi dan Edukasi Protokol Kesehatan Bagi Masyarakat Desa. Dinamisia: $\begin{array}{llll}\text { Jurnal Pengabdian Kepada } & \text { Masyarakat, } & \text { 405-412. }\end{array}$ https://doi.org/10.31849/dinamisia.v5i2.5246

Esti/Suryo. (2020). Unesa Bentuk Unesa Crisis Center (UCC) Untuk Cegah Penyebaran Covid-1. Retrieved March 23, 2020, from Unesa.ac.id website: https://www.unesa.ac.id/unesa-bentukunesa-crisis-center-ucc-untuk-cegah-penyebaran-covid-19

Faizal, A. (2020). Dampak Pandemi Covid-19 di Jatim, 20.036 Tenaga Kerja Dirumahkan, 3.315 DiPHK. Retrieved from Kompas.com website: https://regional.kompas.com/read/2020/04/13/20414411/dampak-pandemi-covid-19-dijatim-20036-tenaga-kerja-dirumahkan-3315-di-phk?page=1

Hartati, S. Syamsuadi, A. \& Elvitaria, L. (2021). Keterlibatan Mahasiswa dan Akademisi dalam Pengabdian Masyarakat Menghadapi Pandemi Covid-19. Dinamisia: Jurnal Pengabdian Kepada Masyarakat, 5(2), 474-480. https://doi.org/10.31849/dinamisia.v5i2.5307

Puspasari, R. (2020). Pemerintah Terbitkan PERPPU untuk Tangani Dampak Ekonomi Akibat Covid-19. Retrieved from Kemenkeu RI website: https://www.kemenkeu.go.id/publikasi/siaran-pers/siaran-pers-pemerintah-terbitkanperppu-untuk-tangani-dampak-ekonomi-akibat-covid-19/

Rahmi, A. Ismanto, H. \& Fathoni, M. Z. (2020). Inovatif Saat Pandemi Covid Melalui Pelatihan Kewirausahaan Khas Perempuan Berbahan Sampah "Kolaborasi BUMDes dan Warga". Dinamisia: Jurnal Pengabdian Kepada Masyarakat, 4(3), 418-425. https://doi.org/10.31849/dinamisia.v4i3.4632

Ronal. (2020). Indef: Pandemi Covid-19 Akibatkan Meningkatnya Jumlah Pengangguran. Retrieved April 9, 2020, from Pasar Dana.id . website: https://pasardana.id/news/2020/4/27/indef-pandemi-covid-19-akibatkan-meningkatnyajumlah-pengangguran/

Wijayanto. (2020). Daya Beli Masyarakat Turun, Jatim Deflasi 0,12 Persen. Retrieved from Radar Surabaya website: https://radarsurabaya.jawapos.com/read/2020/05/05/192444/dayabeli-masyarakat-turun-jatim-deflasi-012-persen

Yarza, H. N., Devi Anugrah, \& Rosi Feirina Ritonga. (2021). Pelatihan Pembuatan Hand Sanitizer Alami dari Daun Sirih. Dinamisia: Jurnal Pengabdian Kepada Masyarakat, 5(3), 800-804. https://doi.org/10.31849/dinamisia.v5i3.4334 